\title{
Fraud Prevention, Mitigation and Management Practices In Nigerian Firms
}

\author{
Akani .N. Fynefaceph.D ${ }^{1}$ MrOladutire, E. Oladeji ${ }^{2}$ \\ Senior Lecturer Department of Accounting, University Of Port Harcourt \\ Department Of Accounting, University Of Benin
}

\begin{abstract}
This paper examined fraud prevention, mitigation and management practices. The respondents were 294 persons drawn from business owners, accountants, investors, bankers, and managers in Port Harcourt. The spearman's rank order correlation coefficient statistical tool of the statistical package for social sciences (SPSS) was used to test the hypotheses. Results indicated that there is a significant relationship between internal control system and reduction in the manipulation of records; and there is a significant relationship between internal auditing and the prevention of assets defalcations. It was concluded that businesses operate in a risky environment where errors and irregularities which may result into fraud can occur. Fraud is an act of deception which is perpetrated by someone in authority for the illegal acquisition of the assets of an organization that he or she is entrusted to take care of. Thus, efficient and effective internal control system with adequate internal auditing should be provided to prevent, mitigate and manage all forms of fraudulent activities in organizations. In the lightof our findings from the study, we recommendedthat the management of firms should have mechanisms for theproper documentations of their assets, and that the management of organizations should provide mechanisms to safeguard all their physical assets.
\end{abstract}

Keywords: Fraud, Fraud Prevention, Mitigation and Management Practices, Internal Control System, Internal Auditing, Manipulations, Defalcations.

\section{Introduction}

Fraud is regarded an irregularity or a deception. It is a means where an individual illegally enricheshimself or herself (Aguolu, 2002).A lot of organizations losses their assets and even close down as a result of fraud related problems. Many cases of corporate collapse in the Nigerian business environment; whether in the public or private sectors are caused by fraudulent government officials or workers.

In most cases, fraud is a product of poor internal control systems in organizations. The mitigation of fraud can be effected if there is an efficient and effective internal control system, which can be applied to nip any fraudulent practice in organizations in the bud (Ama, 2003). Thus, this paper seeks to examine fraud prevention, mitigation and management practices.

\section{Statement Of The Problem}

Studies have indicated that fraud is the number one enemy of the business world, no company is immune to it and it is in all works of life (Aguolu, 2002).Similarly, studies have been carried out on fraud prevention and management Nigeria and globally (Sabo, 2003). This attention is due to the fact that frauddestroys economic and business activities. The idea of fraud mitigation, prevention and management is to prevent organizations from losing their resources which could be put into profitable use (Aguolu, 2002).

Fraud is carried out in many forms in Nigeria and other parts of the world. In most cases fraud comes in the form of manipulations and defalcations. All these, result in the loss of money and valuable resources and assets for businesses and their owners. Hence, this paper seeks to examine how corporate bodies can mitigate, prevent and manage fraud caused by manipulations and defalcations for the growth and survival of organizations.

\section{PURPOSE OF THE STUDY}

This study is intended to investigate fraud prevention, mitigation and management practices. Specifically, the study seeks to find out the following:

1. The extent to which internal controlsystem can reduce manipulation of records.

2. The extent to which internal auditing can prevent assets defalcations.

\section{RESEARCH QUESTIONS}

Concerning the purpose of the study, the following key questions were asked:

1. To what extent can internal control system reduce manipulation of records?

2. To what extent can internal auditing prevent assets defalcations? 


\section{RESEARCH HYPOTHESES}

Concerning the review of related literature, the following hypotheses were developed:

$\mathrm{H}_{1}$ : There is no significant relationship between internal control system andreduction in themanipulation of records.

$\mathrm{HO}_{2}$ : There is no significant relationship between internal auditing and the prevention of assets defalcations.

\section{Theoretical Foundation}

The issue of asset security and safety can best be carried out through a sound internal control system. The objective of internal control is the prevention or early detection of fraud and errors. Internal control is the whole system of controls, financial or otherwise, established by management, in order to secure, as far as possible, the accuracy and reliability of the records, run the business in an orderly manner and safeguard the company's assets (Aguolu, 2002).

Essentially, the management ofan organization is responsible for the prevention and control of fraud. The management is responsible for independently evaluating the adequacy of the existing system of internal control through analysis and testing, and maintaining an adequate system of internal control designed to prevent or detect improper operating activities (Aguolu, 2002; Rezaee, 2002).

\section{Fraud}

\section{Review of Related Literature}

Fraud is a deliberate act (or failure to act) with the intention of obtaining an unauthorized benefit, either for oneself or for the institution, by using deception or false suggestions or suppression of truth or other unethical means, which are believed and relied upon by others. Depriving another person or the institution of a benefit to which he or she it is entitled by using any of the means described above also constitutes fraud (http://sites.tufts.edu/amas/controls-compliance/fraud-prevention/).

Fraud takes many forms. Some examples include: embezzlement, kickbacks, theft, fraudulent financial reporting, environmental crimes, software piracy, bid rigging, computer-related crime, identity theft, credit card fraud, check fraud, fraudulent workers compensation claims, ghost employee schemes, expense report schemes, "dummy" vendors, unreportedconflicts of interest,etc(http://sites.tufts.edu/amas/controlscompliance/fraud-prevention/).

According to Adeniji (2004:354) and ICAN (2006:206), fraud is an intentional act by one or more individuals among management, employees or third parties, which results in a misrepresentation of financial statements. Fraud can also be seen as the intentional misrepresentation, concealment, or omission of the truth for the purpose of deception or manipulation to the financial detriment of an individual or an organization which also includes embezzlement, theft or any attempt to steal or unlawfully obtain, misuse or harm the asset of the organization, (Adeduro, 1998 and, Bostley and Drover 1972).

Fraud has increased considerably over the recent years and professionals believe this trend is likely to continue. According to Brink and Witt (1982), fraud is an ever present threat to the effective utilization of resources and it will always be an important concern of management. ISA 240 'The Auditor's Responsibilities to Consider Fraud in an Audit of Financial Statement (Revised)' refers to fraud as 'an intentional act by one or more individuals among management, those charged with governance, employees or third parties, involving the use of deception to obtain an unjust or illegal advantage". Aderibigbe and Dada (2007) define fraud as a deliberate deceit planned and executed with the intent to deprive another person of his property or rights directly or indirectly, regardless of whether the perpetrator benefits from his or her actions.

\section{Forms Of Fraud}

Weirich and Reinstein (2000 cited in Allyneand Howard 2005), define fraud as "intentional deception, cheating and stealing". Some common types of fraud include creating fictitious creditors, "ghosts" on the payroll, falsifying cash sales, undeclared stock, making unauthorized "write-offs", and claiming excessive or never-incurred expenses.

Pollick (2006) regards fraud as a "deliberate misrepresentation, which causes one to suffer damages, usually monetary losses". Albrecht et al (1995 cited in Allyne and Howard, 2005:287) classified fraud into employee embezzlement, management fraud, investment scams, vendor fraud, customer fraud, and miscellaneous fraud. Fraud also involves complicated financial transactions conducted by white collar criminals, business professionals with specialized knowledge and criminal intent (Pollick 2006).

According to Aguolu (2002), fraud can take place in one of two forms, which are either defalcations or manipulations.

Defalcation is the misappropriation of a company's assets. Manipulation is ether the falsification of a company's records or the improper use of the asset of the company. Defalcation will often go with 
manipulations. Where the assets of a company have been misappropriated, the offender will often after the records to conceal the misappropriation. Manipulations on the other hand, may go without defalcation. This may take the form of inflating the assets oromitting liabilities in order to show a particular view.

However, for the purpose of this paper, the forms of fraud identified by Aguolu (2002) were adopted.

\section{Fraud Prevention, Mitigation and Management Practices}

The following procedures are adopted to help reduce the risk of fraudulent activity occurring within an organization (http://sites.tufts.edu/amas/controls-compliance/fraud-prevention/).Essentially, the procedure involves theestablishment of a positive internal control environment. A genuine interest and concern related to implementing sound internal controls in an organization should be conveyed to all personnel, and the major tenets of an internal control system include: (1) separation of duties; (2) physical safeguards over assets; (3) proper documentation; (4) proper authorizations; (5) adequate supervision; and (6) independent validation of transaction accuracy.

Furthermore, the management of an organization is saddled with the prevention and control of all forms of fraudulent activities by instituting a sound internal control system manned by an internal auditor(Nessuer, 1997).The internal auditor endeavors to reveal any serious defect in systems of internal control which might lead to the perpetration of fraud and must have regard to the possibility of malpractice in areas under examination. He must be alert to the possibility of corruption and be prepared to inform the appropriate level of management of any justifiable suspicions (Nessuer, 1997).

The existence of a properly functioning system of internal controls will diminish the incidents of fraud, so the auditor's opinion on the internal control system is of fundamental importance. Whenever a fraud is discovered, he should judge whether a weakness in internal control has been highlighted, and if so what changes are needed (Nessuer, 1997; David, 1999; Frigo, 2002).

\section{Source of data, population and sampling technique}

\section{Methodology}

Primary data were used for this study, and they were obtained through the administration of welldesigned questionnaire to respondents. The questionnairewas designed based on content validity, and it was measured based on the use of five-point likert-type scale of "to a very great extent $=5$; to a considerable extent $=4$; to a moderate extent $=3$; to a slight extent $=2$; and Not at all $=1$ ".

Using convenience sampling methodology, the questionnaire was handed to 400 respondents in Port Harcourt. The respondents were business owners, bankers, managers, investors and accountants. A total of 294 questionnaires were returned, yielding a 73.5 per cent response rate. Furthermore, more than 90 per cent of the respondents claimed that they were aware of what auditors do. The high level of awareness combined with their accounting qualifications and audit experience are considered as factors that can add credibility to the findings of the research.

\section{Data analysis technique}

The hypotheses for this study were tested using the Spearman's rank order correlation coefficient. The Spearman's order correlation coefficient is usually designated as Rho. It ranks paired observations, thus requiring at least ordinal data. Rho, also symbolized as $r_{s}$ or $p$, measures the degree of relationship between two sets of ranked observations, In other words, it indicates the degree of effectiveness in predicting one-ranked variable based on another ranked variable (Baridam, 2001).

Rho assumes any value from -1 to +1 indicating perfect correlation, and 0 no relationship.The spearman's rank order correlation has the following formula:

$\mathrm{r}_{\mathrm{s}}=1-\frac{6 \sum d^{2}}{N^{3}-N}$ or $=1-\frac{6 \sum d^{2}}{N\left(N^{2}-1\right)}$

Where; $\quad \sum \mathrm{d}^{2}=\quad$ sum of the squared differences in the ranking of

the subject on the two variables.

$\mathrm{N}=$ number of subjects being ranked.

The spearman's rank order correlation co-efficient was adopted by the use of the Statistical Package for Social Sciences (SPSS) version 17.0. The spearman's rank order correlation coefficient was chosen because all the variables in the study are measured in ordinal scale. 


\section{DATA PRESENTATION AND ANALYSIS}

Analysis of Research Questions:

The respondents gave various responses based on the research questions and they are analyzed in the tables below as thus:

Research Question 1: To what extent can internal control system reduce manipulation of records?

Table 1: Effect of internal control system onthe reduction of records manipulation

\begin{tabular}{|l|l|l|}
\hline Item & Frequency & Percentage \\
\hline To a very great extent & 161 & 54.76 \\
\hline To a considerable extent & 78 & 26.53 \\
\hline To a moderate extent & 55 & 18.71 \\
\hline To a slight extent & 0 & 0 \\
\hline Not at all & 0 & 0 \\
\hline Total & $\mathbf{2 9 4}$ & $\mathbf{1 0 0}$ \\
\hline \multicolumn{2}{|l}{ Source: Survey Data, 2013 }
\end{tabular}

The table above shows the responses obtained when it was enquired if internal control system can reduce the manipulation of records in organizations.

Out of the 294 respondents, a total of 161 or $54.76 \%$ provided to a very great extent response to indicate that internal control systemcan reduce the manipulation of records. In addition, 78 (26.53\%) and 55 (18.71\%) of the respondents support this view by respectively providing to a considerable extent and to a moderate extent response. This is because internal control must ensure that records for both accounting and nonaccounting purposes must be kept accurately in a reliable manner. Most management decisions are based on information obtained from the records of the organization. The more accurate and reliable these records are, the better the decisions made by management. To be reliable, these records must be free from any manipulations so as to ensure the completeness, accuracy and validity of the transactions recorded therein. In essence, internal control is applied to secure the accuracy and reliability of the records. It is part of management's duty to approve and set up the system of internal control in the organization (Aguolu, 2002).The objective assessment of internal controls and risk management processes by the internal audit activity provides management, the oversight body, and external stakeholders with independent assurance that the organization's risks have been appropriately mitigated. Because internal auditors are experts in understanding organizational risks and internal controls available to mitigate these risks, they assist management in understanding these topics and provide recommendations for improvements (Rezaee, 2002).

Research Question 2: To what extent can internal auditing prevent assets defalcations?

Table 2: Effect of internal auditing on the prevention ofassets defalcations

\begin{tabular}{|l|l|l|}
\hline Item & Frequency & Percentage \\
\hline To a very great extent & 159 & 54.08 \\
\hline $\begin{array}{l}\text { To a considerable } \\
\text { extent }\end{array}$ & 70 & 22.83 \\
\hline To a moderate extent & 65 & 13.04 \\
\hline To a slight extent & 0 & 0 \\
\hline Not at all & 0 & 0 \\
\hline Total & $\mathbf{2 9 4}$ & $\mathbf{1 0 0}$ \\
\hline
\end{tabular}

Source: Survey Data, 2013

The table above reveals the responses gathered concerning the extent to which internal auditing can prevent assets defalcations in organizations.

Out of the 294 respondents, 159 or $54.08 \%$ provided to a very great extent response to show that internal auditing can prevent assets defalcations. Consequently, $70(23.81 \%)$ and $65(22.11 \%)$ of the respondents support this view by respectively providing to a considerable extent and to a moderate extent response. This is because internal auditing is an independent, objective assurance and consulting activity designed to add value and improve an organization's operations (David, 1999). It helps an organization accomplish its objectives by bringing a systematic, disciplined approach to evaluate and improve the effectiveness of risk management, control, and governance processes. Internal auditing is a catalyst for improving an organization's effectiveness and efficiency by providing insight and recommendations based on 
analyses and assessments of data and business processes. With commitment to integrity and accountability, internal auditing provides value to governing bodies and senior management as an objective source of independent advice. Professionals called internal auditors are employed by organizations to perform the internal auditing activity (David, 1999).The scope of internal auditing within an organization is broad and may involve topics such as the efficiency of operations, the reliability of financial reporting, deterring and investigating fraud, safeguarding assets, and compliance with laws and regulations (Frigo, 2002). Based on the scope of internal auditing, challenges posed by fraud, irregularities and defalcations can be prevented(Frigo, 2002).

\section{Statistical Testing Of Hypotheses}

This section of the study is concerned with the testing of the hypotheses formulated in this paper. The hypotheses testing were done by the use of the Spearman Rank Order Correlation Coefficient statistical tool with the application of the SPSS package version 17.0. The test was adopted because data collected for the study was measured in ordinal scale.

The analysis and interpretation of the results were guided by the correlation decision scale frame of Dana (2001). According to Dana (2001), the correlation decision scale frame is thus:
a) $\pm 0.00-0.19$ (very weak)
b) $\pm 0.20-0.39$ (weak)
c) $\pm 0.40-0.59$ (moderate)
d) $\pm 0.60-0.79$ (strong)
e) $\pm 0.80-0.99$ (very strong)
f) \pm 1 (perfect)

Nonparametric Correlations Matrix: Software Package for Social Sciences (SPSS) Output for Spearman Rank on the Variables.

\begin{tabular}{|c|c|c|c|c|c|}
\hline & Spearman's $\left(r_{s}\right)$ & ICS & RRM & IAD & PAD \\
\hline ICS & $\begin{array}{l}\text { Correlation } \\
\text { coefficient } \\
\text { Sig.(2-tailed) } \\
\mathrm{N}\end{array}$ & $\begin{array}{l}1.000 \\
294\end{array}$ & & & \\
\hline RRM & $\begin{array}{l}\text { Correlation } \\
\text { coefficient } \\
\text { Sig.(2-tailed) } \\
\text { N }\end{array}$ & $\begin{array}{l}.539 * * \\
.000 \\
294\end{array}$ & $\begin{array}{l}1.000 \\
294\end{array}$ & & \\
\hline IAD & $\begin{array}{l}\text { Correlation } \\
\text { coefficient } \\
\text { Sig.(2-tailed) } \\
\text { N }\end{array}$ & $\begin{array}{l}.665 * * \\
.000 \\
294\end{array}$ & $\begin{array}{l}.771^{* *} \\
.000 \\
294\end{array}$ & $\begin{array}{l}1.000 \\
294\end{array}$ & \\
\hline PAD & $\begin{array}{l}\text { Correlation } \\
\text { coefficient } \\
\text { Sig.(2-tailed) } \\
\mathrm{N}\end{array}$ & $\begin{array}{l}.753 * * \\
.000 \\
294\end{array}$ & $\begin{array}{l}.763 * * \\
.000 \\
294\end{array}$ & $\begin{array}{l}.787^{* * *} \\
.000 \\
294\end{array}$ & $\begin{array}{l}1.000 \\
294\end{array}$ \\
\hline
\end{tabular}

Source: SPSS Output, 2013

ICM=Internal Control System

RRM= Reduction of Records Manipulation

$\mathrm{IAD}=$ Internal Auditing

$\mathrm{PAD}=$ Prevention of Assets Defalcations

\section{HYPOTHESIS 1:}

$\mathrm{HO}_{1}$ : There is no significant relationship between internal control system and reduction in the manipulation of records.

Table 3: Correlation Matrix on the relationship between internal control system and reduction of records manipulation

\begin{tabular}{|l|l|l|l|}
\hline & Statistics & Internal Control System & $\begin{array}{l}\text { Reduction of Records } \\
\text { Manipulation }\end{array}$ \\
\hline $\begin{array}{l}\text { Internal Control } \\
\text { System }\end{array}$ & $\mathrm{r}_{\mathrm{s}}$ & 1.000 & 0.771 \\
\hline & Z-crit & & 1.960 \\
\hline & Zr-cal & & 13.197 \\
\hline $\begin{array}{l}\text { Reduction of } \\
\begin{array}{l}\text { Records } \\
\text { Manipulation }\end{array}\end{array}$ & $\mathrm{N}$ & 294 & 294 \\
\hline & $\mathrm{r}_{\mathrm{s}}$ & 0.771 & 1.000 \\
\hline
\end{tabular}

Source: Survey Data and SPSS Output, 2013, version 17.0 
Correlation is significant at 0.05 level (2-tailed)

The table above shows SPSS output for the Spearman's Rank Order Correlation Coefficient test between internal control system and reduction in the manipulation of records. The Spearman's Rank Order Correlation Coefficient is computed at 0.771 and $p$ (2-tailed) $<0.05$ for d.f $=292$ (where d,f $=$ degree of freedom and is given as $\mathrm{N}-2$. However, we noted a strong and positive relationship betweeninternal control system and reduction in the manipulation of records, $\mathrm{r}_{\mathrm{s}}=0.771$ (292), $\mathrm{p}$ (2-tailed) $<0.05$. Thus, since $\mathrm{Zr}$-calof 13.197 is greater than Z-crit of 1.960 , the null hypothesis $\left(\mathrm{HO}_{1}\right)$ is rejected in favor of the alternative hypothesis $\left(\mathrm{Ha}_{1}\right)$. Therefore, we stated that there is a significant relationship between internal control system and reduction in the manipulation of records.

\section{HYPOTHESIS 2:}

$\mathrm{HO}_{2}$ : There is no significant relationship between internal auditing and the prevention of assets defalcations.

Table 4: Correlation Matrix on the relationship between internal auditing and the prevention of assets defalcations

\begin{tabular}{|l|l|l|l|}
\hline & Statistics & Internal Auditing & $\begin{array}{l}\text { Prevention of Assets } \\
\text { Defalcations }\end{array}$ \\
\hline $\begin{array}{l}\text { Internal } \\
\text { Auditing }\end{array}$ & $\mathrm{r}_{\mathrm{s}}$ & 1.000 & 0.787 \\
\hline & Z-crit & & 1.960 \\
\hline & Zr-cal & & 13.471 \\
\hline & $\mathrm{N}$ & 294 & 294 \\
\hline $\begin{array}{l}\text { Prevention of } \\
\text { Assets } \\
\text { Defalcations }\end{array}$ & $\mathrm{r}_{\mathrm{s}}$ & 0.787 & 1.000 \\
\hline & $\mathrm{N}$ & 294 & 294 \\
\hline
\end{tabular}

Source: Survey Data and SPSS Output, 2013, version 17.0

Correlation is significant at 0.05 level (2-tailed)

The table above shows SPSS output for the Spearman's Rank Order Correlation Coefficient test betweeninternal auditing and the prevention of assets defalcations. The Spearman's Rank Order Correlation Coefficient is computed at 0.787 and p (2-tailed) $<0.05$ for d.f $=292$ (where d,f $=$ degree of freedom and is given as $\mathrm{N}-2$ ). However, we noted a strong and positive relationship between internal auditing and the prevention of assets defalcations, $r_{s}=0.787$ (292), $p$ (2-tailed) $<0.05$. Hence, because $\mathrm{Zr}$-cal of 13.471 is greater than Z-crit of 1.960 ,the null hypothesis $\left(\mathrm{HO}_{2}\right)$ is rejected in favor of the alternative hypothesis $\left(\mathrm{Ha}_{2}\right)$. Therefore, we stated that there is a significant relationship between internal auditing and the prevention of assets defalcations.

\section{Discussion of Findings, Conclusion And Recommendations}

\section{Discussion of findings:}

This section provides the discussionof findings on fraud prevention, mitigation and management practices. Hypotheses were put forward and analyzed by the use of the Spearman's Rank Order Correlation Coefficient based on the application of the SPSS package (version 17.0). The section is guided by previous findings as shown by the review of literature. The reason for this is to create a basis for drawing conclusion on the findings of the study and to make recommendations accordingly.

\section{Relationship between internal control system and reduction of records manipulation}

Hypothesis 1 was formulated to determine the relationship between internal control system and reduction of records manipulation. The result of the test revealed a spearman correlation coefficient $\left(\mathrm{r}_{\mathrm{s}}=0.771\right.$, $\mathrm{p}<0.05$ ) (see table 3). The literature review of the present study suggested a positive relationship between internal control system and reduction of records manipulation(Adeniji, 2004; and ICAN, 2006). This is because fraud is an intentional act by one or more individuals among management, employees or third parties, which results in a misrepresentation of financial statements (Adeniji, 2004; and ICAN, 2006). Fraud is also seen as the intentional misrepresentation, concealment, or omission of the truth for the purpose of deception or manipulation to the financial detriment of an individual or an organization which also includes embezzlement, theft or any attempt to steal or unlawfully obtain, misuse or harm the asset of the organization(Adeduro, 1998; Bostley and Drover 1972).

Relationship between internal auditing and the prevention of assets defalcationsHypothesis 2 was meant to find out the relationship betweeninternal auditing and the prevention of assets defalcations. The result of the test indicated a spearman correlation coefficient $\left(\mathrm{r}_{\mathrm{s}}=.787, \mathrm{p}<0.05\right)$ (see table 4). The literature review of the present 
study suggested that there is a positive relationship between internal auditing and the prevention of assets defalcations(Nessuer, 1997). This is because the management is saddled with the prevention and control of all forms of fraudulent activities by instituting a sound internal control system manned by an internal auditor (Nessuer, 1997). Consequently, thetenets of an internal control system and internal auditing should be directed towards physical safeguards over assets (http://sites.tufts.edu/amas/controls-compliance/fraud-prevention/).

\section{Conclusion}

This paper examined fraud prevention, mitigation and management practices. The present study empirically tested two hypotheses:(1) there is no significant relationship between internal control system and reduction in the manipulation of records; and (2) there is no significant relationship between internal auditing and the prevention of assets defalcations.

All two hypotheses were confirmed. The empirical analysis confirmed an existence of a positive link with the forms of fraud and the processes of fraud prevention, mitigation, and management practices.

The forms of fraud were noted as manipulations of records and assets defalcations (Aguolu, 2002). While, the approaches used to prevent, mitigate and manage fraud were based on the application of sound internal control system and internal auditing (Nessuer, 1997; David, 1999; Frigo, 2002).

Based on our analysis, we discovered that internal control system enhances the practice of fraud prevention, mitigation and management. Typically, the tenets of sound internal control were considered to be(1) separation of duties; (2) physical safeguards over assets; (3) proper documentation; (4) proper authorizations; (5) adequate supervision; and (6) independent validation of transaction accuracy(http://sites.tufts.edu/amas/controlscompliance/fraud-prevention/). This was revealed by the spearman's rank order correlation coefficient from the tests of hypothesis 1 , which was $\left(\mathrm{HO}_{1}: \mathrm{r}_{\mathrm{s}}=.771\right)$. Therefore, investigation on the application ofinternal control system for the reduction of records manipulationis more valid and accurate (Nessuer, 1997; David, 1999; Frigo, 2002; Aguolu, 2002; Rezaee, 2002). Sound internal controlsystem is relevant for the prevention, mitigation and management of fraud in organizations.

Second, internal auditing is a veritable tool forthe prevention, mitigation and management. Internal auditing provides internal controls for the organization in order to ensure that all risks and fraudulent activities are appropriately mitigated.This was revealed by the spearman's rank order correlation coefficient from the tests of hypothesis 2 , which was $\left(\mathrm{HO}_{2}: \mathrm{r}_{\mathrm{s}}=787\right)$. Therefore, investigation on the use of internal auditing for the prevention of assets defalcations is more valid and accurate (David, 1999; Frigo, 2002; Aguolu, 2002).

Consequently, we could conclude that businesses operate in a risky environment where errors and irregularities which may result into fraud can occur. Fraud is an act of deception which is perpetrated by someone in authority for the illegal acquisition of the assets of an organization that he or she is entrusted to take care of.Thus, efficient and effective internal control system with adequate internal auditing should be provided to prevent, mitigate and management all forms of fraudulent activities.

\section{Recommendations:}

In the light of our findings from the study, we recommended as follows:

That the management of organizations should provide sound internal control system to check all corporate activities.

That the management of organizations should make use of competent internal auditors in their internal control system.

That the management offirms should ensure the separation of duties.

Thatthe management offirms should provide proper authorizations for all transactions.

That the management offirms should have mechanisms for the proper documentations of their assets.

That the management of organizations should provide mechanisms to safeguard all their physical assets.

\section{REFERENCES}

[1]. Adeduro, A.A. (1998): “An investigation into frauds in banks". An unpublished thesis of University of Lagos.

[2]. Adeniji, A. (2004): Auditing and Investigation. Lagos: Value Analysis Publishers.

[3]. Aderibigbe, P. (1997): Auditing: Conceptual Emphasis. Ibadan: Lyons Ltd

[4]. Aderibigbe, P. and Dada, S. O. (2007): Microauditing Principles. Lagos: ICAN Students Journal.Vol 11 No 1, Jan/March.

[5]. Aguolu, O. (2002). Fundamentals of Auditing, Enugu: Meridian Associates.

[6]. Alleyne, P., and Howard, M. (2005): An exploratory study of auditors' responsibility for fraud detection in Barbados. Managerial Auditing Journal. 20(3):284-303.

[7]. Ama, G.A.N. (2003).Fundamentals of Public Sector Accounting and Finance. Aba: Amasons Publications Ventures.

[8]. Baridam, D. M. (2001) Research Methods in Administrative Sciences, Port Harcourt: Sherbrooke Associate Revised Edition).

[9]. Bostley R.W.B. and Dover C.B. (1972): Sheldon's practice and law of banking, $10^{\text {th }}$ ed London: Macdonald and Evans.

[10]. Brink, V.Z., and Witt, H. (1982), Internal Auditing. New York: John Wiley and Sons: Dana, S.D. (2001). Statistics and Data Analysis for Behavioral Science. New York: McGraw Hill Co.

[11]. David, H. (1999). Audit Principles Risk Assessment and Effective Reporting. New York: SANS Press.

[12]. Fraud prevention. Accessed on:http://sites.tufts.edu/amas/controls-compliance/ fraud-prevention/. Retrieved on: 15 March, 2013. 
[13]. Frigo, M. L. (2002). A Balanced Scorecard Framework for Internal Auditing Departments.IIA Research Foundation. Altamonte Springs, FL.

[14]. ICAN (2006): Financial Reporting and Audit Practice. Lagos, VI Publishing Ltd (The Institute of Chartered Accountants of Nigeria).

[15]. Nessuer, W.F. Jr (1997): Auditing: A Systematic Approach. New York: Irwin McGraw-Hill.

[16]. Pollick, M.Y. (2006). What is Fraud: Accessed onhttp://www.wisegeek.com/ what-is-fraud.htm.Retrieved on: 15 March, 2013.

[17]. Rezaee, Z. (2002). Financial Statement Fraud: Prevention and Detection. New York: Wiley.

[18]. Sabo, B. (2003). "Fraud Prevention and Control in Nigerian Public Service: Theneed for a dimensional

[19]. approach". An Article of theDepartment of Business Administration, Faculty of Administration,Ahmadu BelloUniversity, Zaria Nigeria.

\section{APPENDIX 1}

Instruction:Please, kindly tick $(\sqrt{ })$ in the appropriate boxes that applies to you by using the followings options. To a very great extent $=5 ;$ To a considerable extent $=4 ;$ To a moderate extent $=3$;

To a slight extent $=2$; and Not at all $=1$.

FRAUD MITIGATION, PREVENTION AND MANAGEMENT

\begin{tabular}{|c|c|c|c|c|c|c|}
\hline S/N & Questions & 5 & 4 & 3 & 2 & 1 \\
\hline 1. & $\begin{array}{l}\text { To what extent are you acquainted with the practice of } \\
\text { auditing and accounting in the fight of fraudulent } \\
\text { practices in organizations? }\end{array}$ & & & & & \\
\hline 2. & $\begin{array}{l}\text { To what extent does the establishment of internal } \\
\text { control system help to curb fraud in your } \\
\text { organization? }\end{array}$ & & & & & \\
\hline 3. & $\begin{array}{l}\text { To what extent does the application of relevant } \\
\text { authorization of transactions prevent the occurrences } \\
\text { of irregularities in your company? }\end{array}$ & & & & & \\
\hline 4. & $\begin{array}{l}\text { To what extent does the physical safeguard over assets } \\
\text { aid in fraud mitigation? }\end{array}$ & & & & & \\
\hline 5. & $\begin{array}{l}\text { To what extent does proper documentation reduce the } \\
\text { manipulations of financial records? }\end{array}$ & & & & & \\
\hline 6. & $\begin{array}{l}\text { To what extent does adequate supervision of } \\
\text { transaction help to curb fraud? }\end{array}$ & & & & & \\
\hline 7. & $\begin{array}{l}\text { To what extent does the separation of duties help to } \\
\text { curb fraud? }\end{array}$ & & & & & \\
\hline 8. & $\begin{array}{l}\text { To what extent does your company use internal } \\
\text { auditing to independently validate the accuracy of her } \\
\text { transaction? }\end{array}$ & & & & & \\
\hline 9. & $\begin{array}{l}\text { To what extent is whistle blowing used to prevent } \\
\text { fraud in your company? }\end{array}$ & & & & & \\
\hline 10. & $\begin{array}{l}\text { To what extent has external auditing been used to } \\
\text { detect fraud in your firm? }\end{array}$ & & & & & \\
\hline
\end{tabular}

Source: Survey Data, 2013 